\title{
When I'm Sixty-Four: Beatles Rock Band and the Commodification of Nostalgia
}

\author{
Jaigris Hodson \\ York/Ryerson Universities \\ jaigris@jaigrishodson.com
}

\begin{abstract}
In 2009, only a few months after the game's release, the popular trade magazine Advertising Age declared Beatles Rock Band (2009) one of America's hottest brands ("America's hottest brands", 2009). This is quite a feat for a video game, and begs that we consider the reasons for the game's success as well a the potential social consequences of this game as well as similar popular games.

There are two major elements at work in the creation of Beatles Rock Band as a successful brand, and this paper conducts qualitative, participant-observation research in order to provide an analysis of the game that identifies both of them. First, the paper explores the Beatles as a brand that continues to provide emotional and spiritual value for consumers, and how the feelings associated with this brand have developed intertextually since the band first gained international popularity in 1962. Second, this paper will show how Beatles Rock Band can be viewed as a documentary game, and how, in portraying history, it also rewrites it in order to capitalize on a romanticized ideal of 1960s culture. This paper will show the ways that Beatles Rock Band draws on previous commercial texts associated with the Beatles brand to create a hyperreal fiction based on historic people and events. These texts help to connect people in fan communities that serve the commercial purposes of the game marketers. Despite the extensive commodification of nostalgia present in the text of this game however, the gap between the fictionalized nostalgia portrayed in the game and reality may yet serve to reveal the game as a fantasy for those who care to adopt an oppositional reading of this text. And while not all players will adopt this sort of reading, the complex nature of in-game identity formation suggests that the commodified discourses may not be totalizing ones for all players.
\end{abstract}

\section{Author Keywords}

Digital games; Rock Band; Harmonix; Beatles; digital play; commodification; branding; nostalgia; subjectivity

\section{Introduction - Money (That's What I Want)}

Video games have traditionally been popular among a demographic of teens and young adults between the ages of 19 and 29 (Pew Internet and American Life Project, 2007). However, new video game systems such as Nintendo's Wii, and games such a the New York Times Crossword (2007) and Brain Age (2005), are beginning to reach out to an older demographic that includes baby boomers and older adults. The latest addition to this offering is a variation on the popular 
musical game Rock Band (2007). Released in time for Christmas 2009, Beatles Rock Band allows users to play their way through the Fab Four's career as John, Paul, George or Ringo. Whereas video games have traditionally been one way that corporations seek to commoditize children's play (Kline, Dyer-Witheford, \& De Peuter, 2005), Beatles Rock Band involves the commodification of nostalgia through video gaming, and this strategy seems to be working very well. Beatles Rock Band was declared one of America's hottest brands in 2009 by the popular trade magazine Advertising Age ("America's hottest brands", 2009).

There are two major elements at work in the creation of Beatles Rock Band as a successful brand, and this paper will conduct a content analysis of the game in order to identify both of them. It follows from the work of Kline, Dyer-Witheford, and De Peuter in their book Digital Play (2005), but whereas Kline, Dyer-Witheford and De Peuter studied multiple video games that were targeted primarily at children and young adults, this paper focuses on a single game aimed at an older demographic. In addition to drawing from Digital Play, this paper explores the ideas of the Beatles as both a documentary game, following Poremba (2009) and Fullerton (2008), and the Beatles as a highly successful transmediated brand following from the work of Lury (2004), Jenkins (2006) and others. First of all, the paper will explore the ways that the Beatles brand has eclipsed any reality associated with individual band members via postmodern caricatures that continue to provide emotional and spiritual value for consumers. The feelings associated with the Beatles as a brand have developed intertextually since they first gained international popularity in 1962, and Beatles Rock Band has capitalized on this resilient brand image through the remediation of different past media forms into game space. Secondly, this paper will use qualitative analysis of the game itself to show how Beatles Rock Band works to rewrite history in an attempt to capitalize on the nostalgia of its target demographic. In doing so, the game produces a false sense of community and history which encourages a hyperreal relationship to commodity over community (Turkle, 2011), that serves the commercial interests of the game company even among fan communities forming at sites outside the game space. Despite this, however, the game is not a totalizing force. In recognition of this fact, this paper will end with an examination of the ways that game players could take an oppositional reading of the history portrayed in the text. It suggests the ways that the fantastic game images may work at crosspurposes to the preferred reading of the text and identifies opportunities for resistant discourses to occur.

\section{With a little help from my friends: A theoretical overview of convergence, remediation and the business of entertainment}

In digital communities, discourses shape both the perceptions and (through perceptions) the behaviors of people - they can support or undermine gender identity, help create norms for discipline in the classroom and govern the way that people participate in online communities (Foucault, 1980; Butler, 1990; Pentzold \& Seidenglanz, 2006). As Terranova (2009) stated, discourses also give us ideas about how the economy works, and creates people as social actors within a community where larger organizations have something to gain from the material and immaterial labour of others (Cote \& Pybus, 2007).

When discourses are transmitted and engaged with in a digital space, the medium of transmission adds an additional layer of complexity to the analysis. Theorists such as Bolter and Grusin 
(1999), Jenkins (2006), Dyer-Witheford, Kline and DePeuter (2005), and Bogost (2008), have looked at the ways people interact with digital technologies when they engage with each other within the greater system of cultural production and consumption. They suggest that part of the persuasive appeal of digital media comes from remediation, which can be described as layers upon layers of mediation, or media which build on earlier media in which users may or may not be aware of the mediation. For the cultural industry, digital media are potential gold mines, since they offer ample opportunities for companies to market the same product multiple times across different media. In other words, new digital media have dramatically lowered the cost of creating and distributing cultural products across a variety of platforms. This means that any given media text can be circulated and recirculated multiple times across different distribution channels, creating multiple revenue streams from the same product. While this trend benefits traditional media distributors, it can also support smaller grassroots involvement in the creation and recirculation of alternative texts. Fan communities can, with the growing popularity of relatively inexpensive digital tools, adapt, remix, and share their own versions of popular cultural products. Henry Jenkins (2006) calls this phenomena convergence and notes that it is becoming more popular to release expensive media products like film on many different devices such as smartphones, tablets, or gaming consoles, meaning that each individual now experiences a media product in different ways and via different channels as a result of the virtualization of cultural products via digital media.

Digital media are simultaneously mediated and yet also transparent for the user (Bolter \& Grusin, 2000). In other words, the user of digital media is often acutely aware that she is engaging in a mediated experience, but is also easily able to get lost in the experience and ignore or forget about the mediation. This concurrent mediation and transparency occurs because though digital technology tries to be seamless in its interface for the user, it depends on earlier forms of media television, film, recorded music - in order to make sense. The problem is that when this occurs a false feeling of authenticity of an experience is created (Bolter \& Grusin, 1999). When a user experiences this kind of hypermediacy, he may get trapped by a media environment just as narcissus was trapped by his reflection in the pool (McLuhan, 1964). This narcissus narcosis potentially leads to interactions in which we become tethered to our personal technologies in a potentially unhealthy way (Turkle, 2011). Games are an interesting study of remediation, however, because they are also sites of discursive self-fashioning and personal reflection (Turkle, 1995). Game players often work through their own identities with the avatars that they are playing, entering a type of liminal identity space as they work with their in-game character (Boudreau, 2009), and as such game play can open up new opportunities to both engage with dominant discourses and also resist them (Parker, 2008; Poremba, 2010).

\section{What goes on: a review of the methodology of interactive video gaming}

In this study, cues were taken from previous studies into video gaming which offered a detailed look at game content (Kline, Dyer-Witheford \& De Peuter, 2005; Poremba, 2009; Fullerton, 2008) and following these studies, participant observation and a textual analysis of the game were conducted. Research was conducted from January through April 2010 and included repeat viewings of the introductory game video as well as the repeated participant observation and playing of the game using different 'instrument' controllers. It also included a review of downloadable content for the game. Analysis of Beatles Rock Band as a digital text followed the 
work of such theorists as Fuller and Jenkins (1995), Poblocki (2002), and Milaucic (2006), and included both the regular game content as well as analysis of all the downloadable extra songs available as of April 2010.

In practice, I have tried to take Markham's (2006) advice and engage in research with this game as part of an iterative process that takes into account larger sense-making frameworks that both inform and are informed by the game. Of particular interest to this paper were the following questions: what imagery is being used and associated with each musical track? How are the people in the band being portrayed as individuals? How is drug use and eastern spirituality represented or not represented in the images of the band? How is the game consistent with the current branding for both the Rock Band Franchise and the Beatles brand? And finally, how does the story of the band differ from actual recorded history of the Beatles? Before answering these questions in this paper, I will provide a brief overview of the game itself, its popularity, and some of its content.

\section{A day in the life: An Overview of Beatles Rock Band}

In 2007, after the overwhelming success of the Guitar Hero franchise for Nintendo and Sony game consoles, video game company Harmonix introduced a new generation in rhythm games. Rock Band experienced a successful release in time for Christmas, 2007 ("Rock Band", 2010). The pitch? Like Guitar Hero, players played a digital instrument in time to the music to earn points - but in Rock Band, up to four players could play at once using a variety of instruments: guitar, bass guitar, drums, and vocals. The formula was a success, and Rock Band spawned sequels and expansion packs with which players could expand their repertoire of song choices as well as play with digital representations of rock stars including Kurt Cobain, Johnny Cash and Shirley Manson. Following the commercial success of Rock Band and Rock Band 2, Harmonix signed a deal with Apple Corps Limited to produce the first Rock Band game exclusively associated with a specific rock group: Beatles Rock Band (Beatles Rock Band, 2010). The game was released in September 2009, and could be played with the regular Rock Band guitar, drum, and microphone controllers, although a special edition pack offered players the chance to use controllers that looked like the Beatles' actual instruments - at an extra cost. The basic game offers 45 different Beatles tracks, spanning the career of the Fab Four. Extra songs - including the complete Sgt. Pepper's Lonely Hearts Club Band, Abbey Road, and Rubber Soul albums are also available for sale online. To date, the combination of the Beatles band with the Rock Band franchise has been incredibly successful.

When a player sits down to play the game, she is greeted with a kaleidoscope of colourful imagery to compliment the sound of digitally enhanced Beatles' songs. For example, the opening cinematic for the game starts with images that reference the 1964 film Hard Days Night. The cinematic depicts the young lads from Liverpool, dressed in their iconic grey suits and mop-top haircuts, running from crowds of screaming girls. They jump into a car and speed away, only to have the scenery around them shift from Hard Day's Night to the Beatles' first North American television appearance on the Ed Sullivan Show (Figure 1). After the Ed Sullivan Show, the scene shifts again. Next, the video shows the Fab Four climbing a staircase in their Sergeant Pepper's Lonely Hearts Club Band costumes (Figure 2), but when they get to the top of the staircase, there is nothing there, so they use umbrellas to parachute off the top of the staircase and into a 
garden on the head of a giant elephant that seems to reference the Hindu god Ganeshsa (Figure 3). The Ganesh-Elephant is leading a crowd of marching 'eggmen' and 'elementary penguins', a cartoony reference to the song "I Am the Walrus". Finally, the Ganesh-Elephant/Beatle transport system marches to the edge of a cliff and the procession stops with the four Beatles standing proudly on top of the Ganesh-Elephant with their hands raised. This entire sequence occurs to a medley of parts of the following songs (in order): "Twist and Shout", "Hard Days Night", "Paperback Writer", "Here Comes the Sun", and "I am the Walrus".

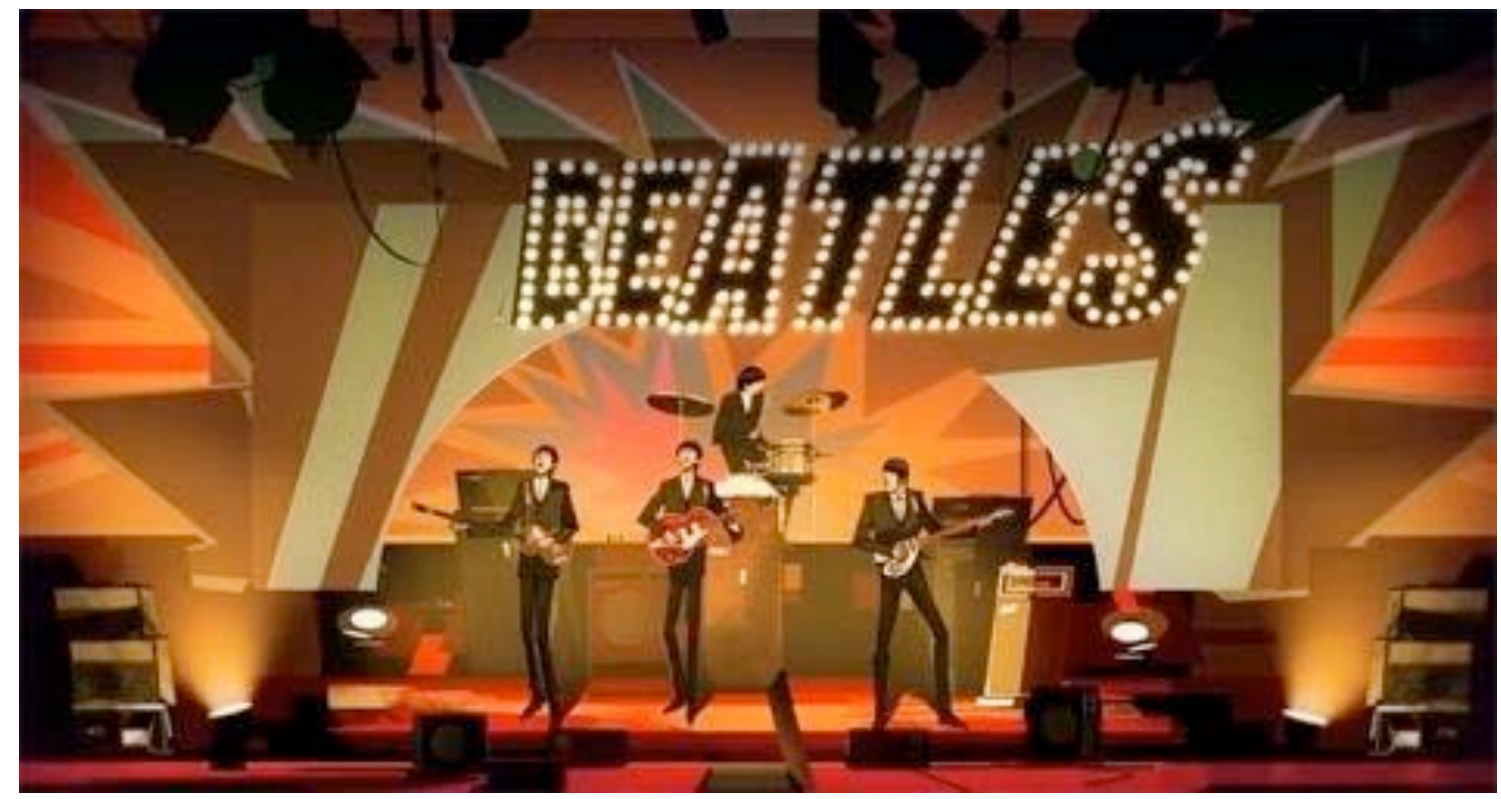

Figure 1: A still from the opening cinematic portraying the Beatles on the Ed Sullivan Show

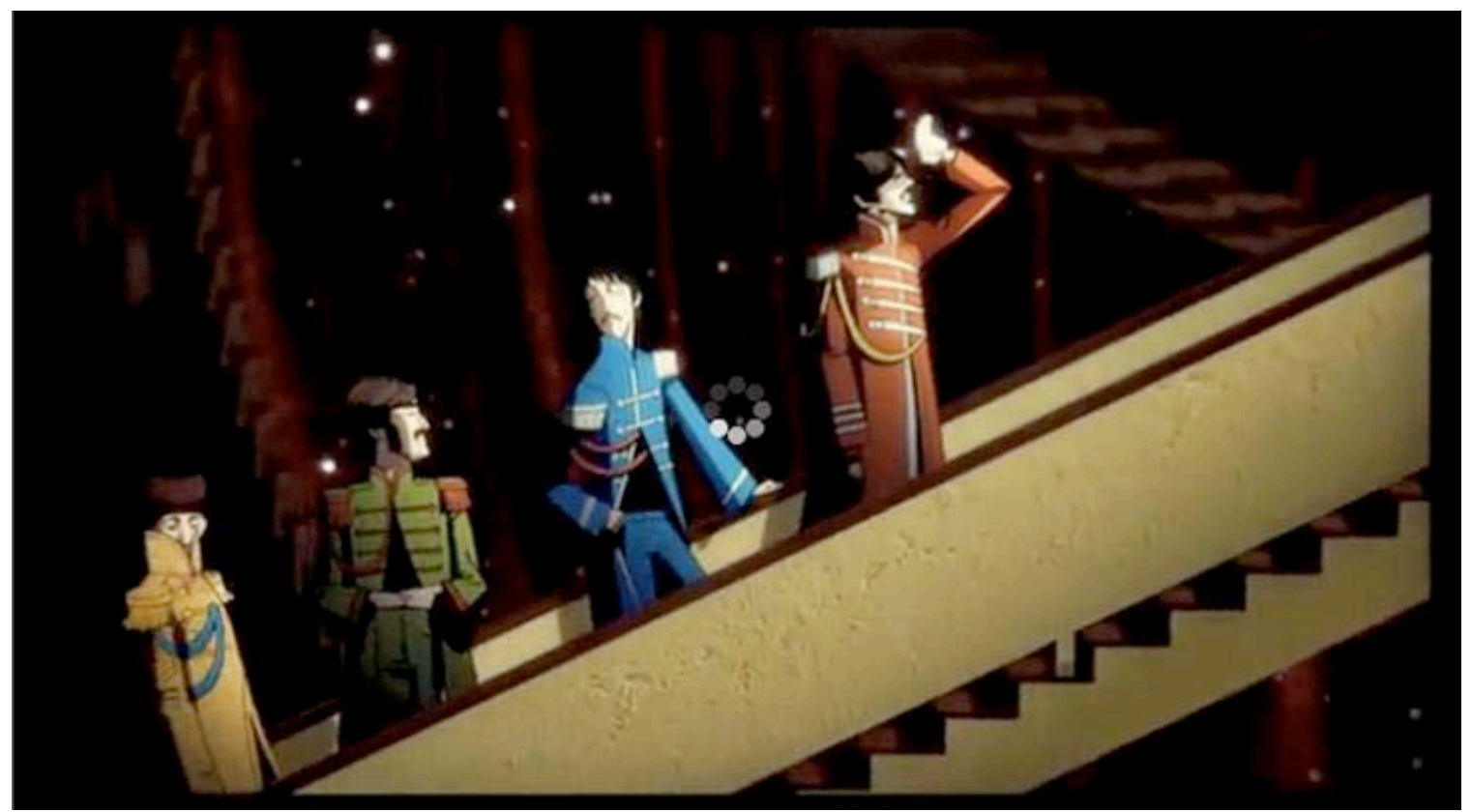

Figure 2: A still from the opening cinematic showing the Beatles in their Sgt. Peppers costumes. 


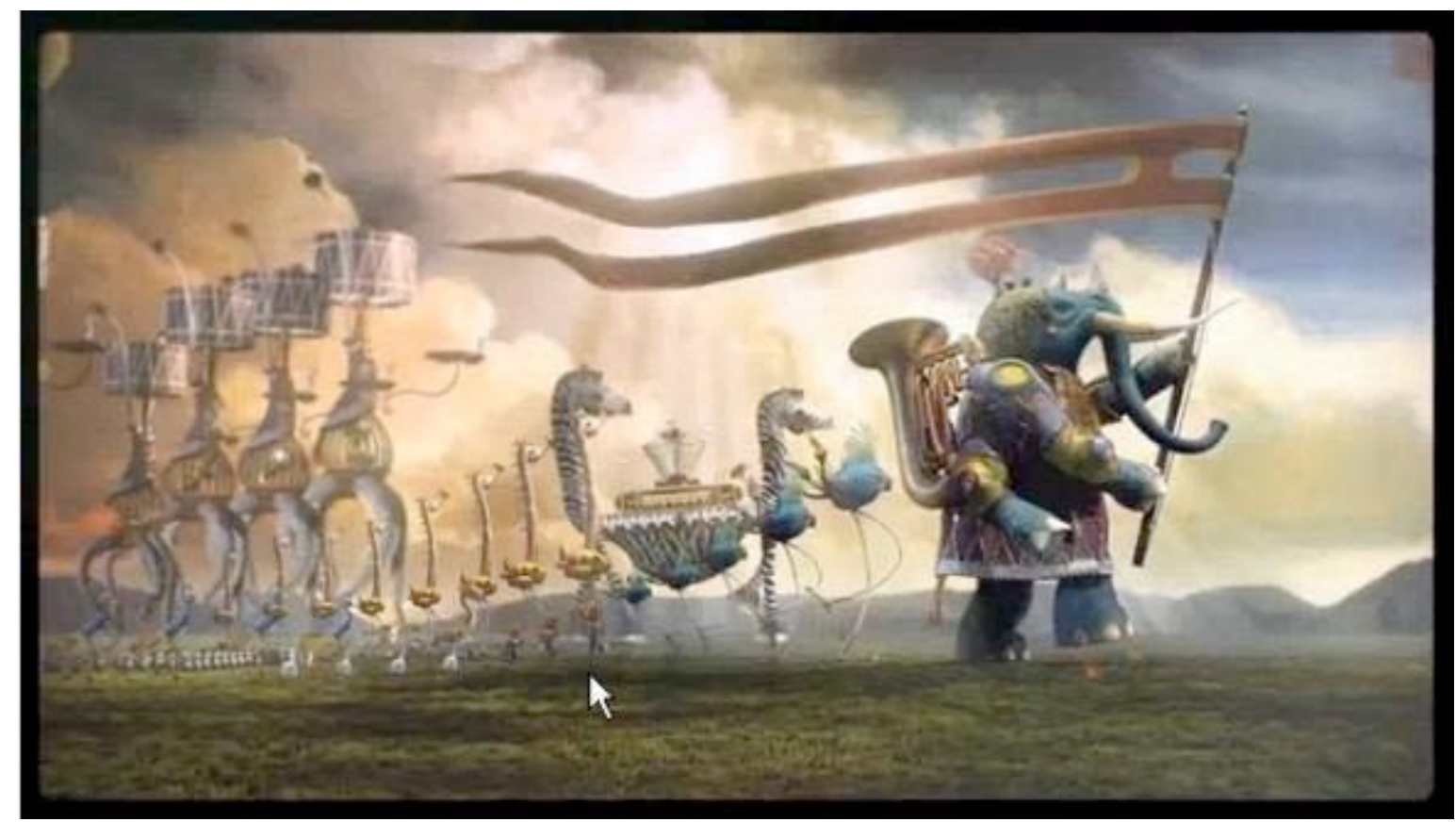

Figure 3: A still from the opening cinematic depicting the large elephant, eggmen, and elementary penguins.

When a person plays Beatles Rock Band, he can choose to sing up to three vocal parts, and/or he can play lead guitar, bass guitar, or drums. One to six people can play the game together, in the same room or remotely via the internet. As each song plays, a video plays that reflects an image of the Beatles that is appropriate for the look of the band at the time the song came out. For example, when a player chooses to play the track "Twist and Shout," she is shown an accompanying video of a very young looking Fab Four playing in a digital representation of the famous Cavern club (Figure 4). However, when a player chooses to play "Get Back", a song released shortly before the band broke up, she is shown a video of the Beatles with longer hair, playing on the roof of the Apple corps 1td. building (Figure 5). Notably, no in-game representation of the Beatles depicts a scruffy circa 1969 version of the band. In-game representations of the Beatles are kept mostly clean-shaven throughout the portrayed history (Figures 6 and 7). 


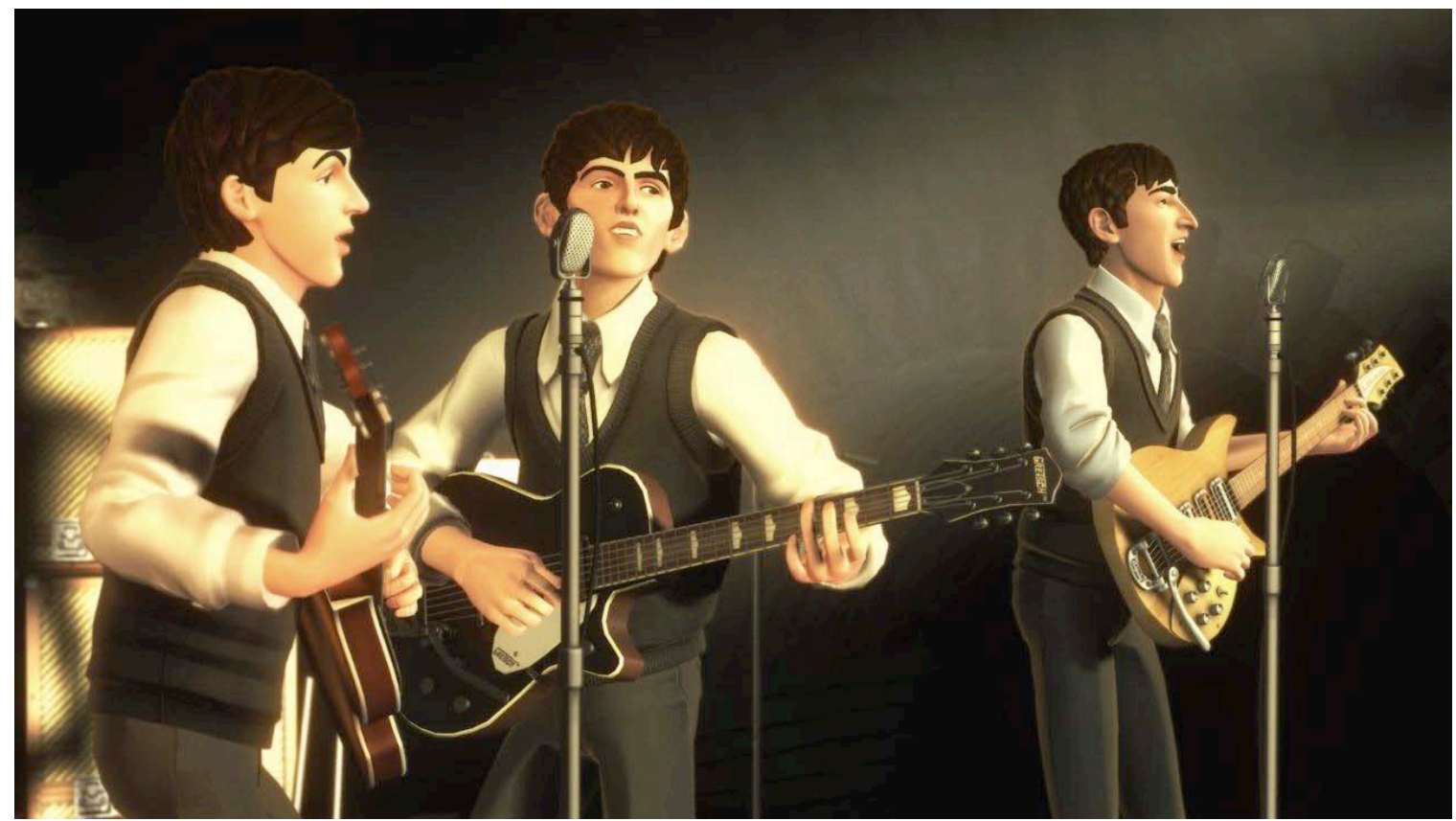

Figure 4: A still from early in the game depicting the Beatles playing the iconic Cavern club

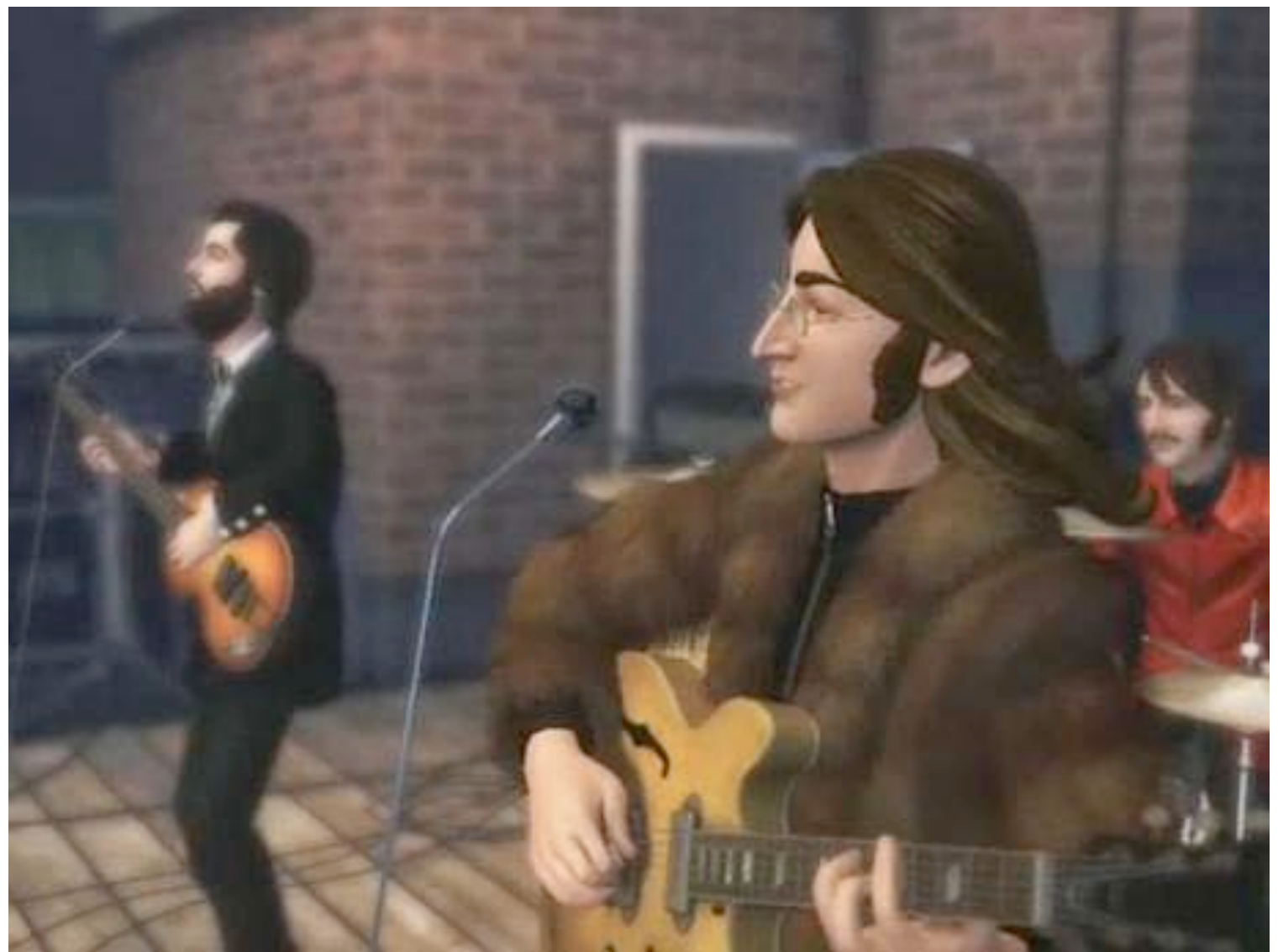

Figure 5: A still from late in the game depicting the Beatles on the rooftop of the Apple corps building. 


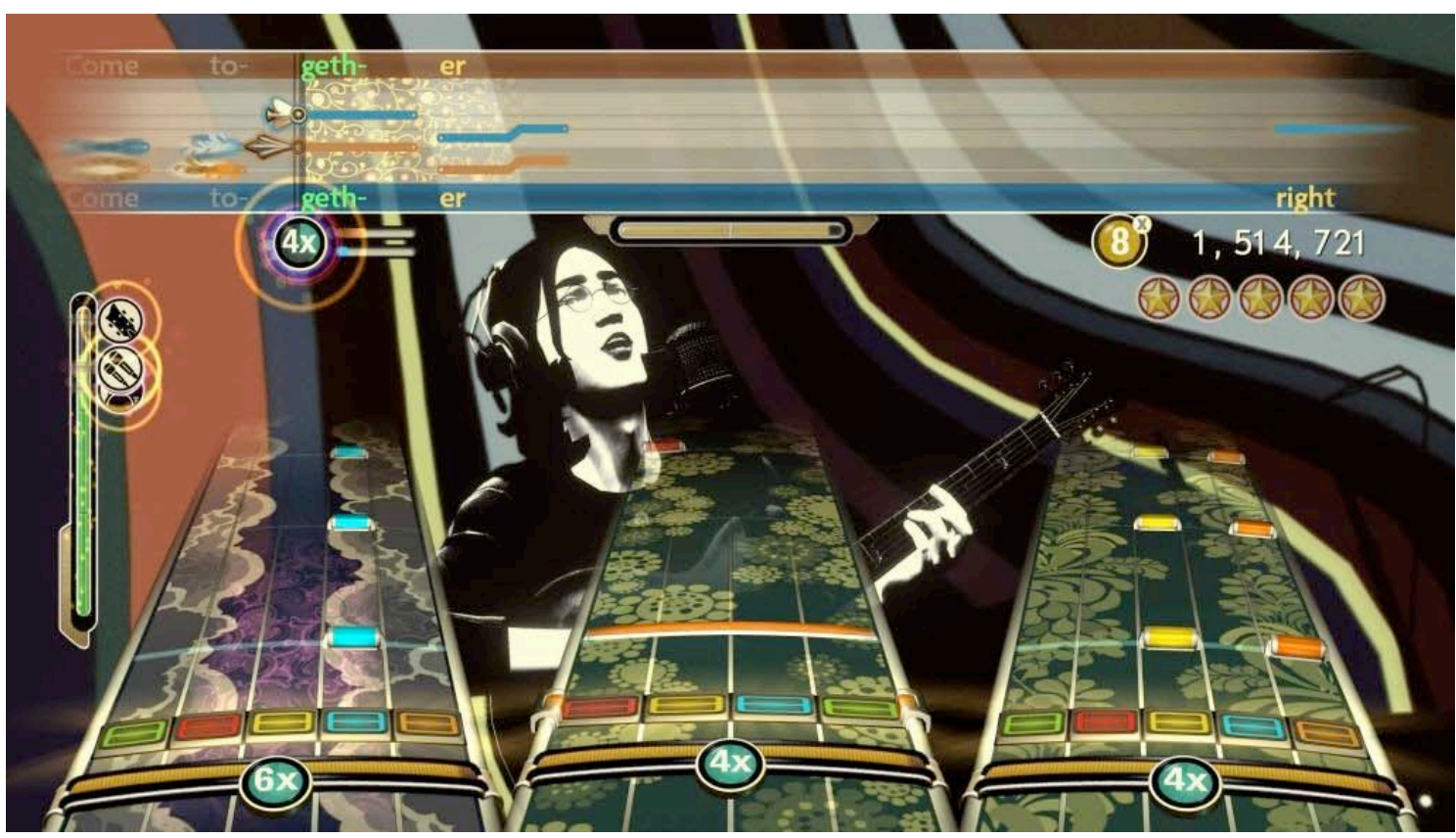

Figure 6: A still from the "Come Together" video

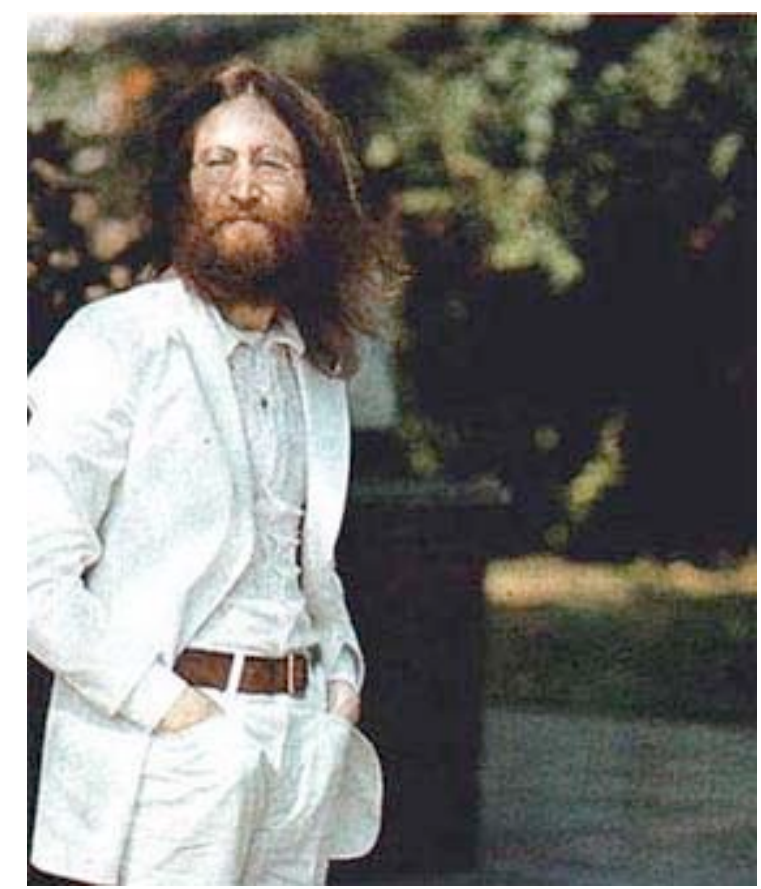

Figure 7: John Lennon Photograph from the Abbey Road album.

Notice the difference between this photo and his image in Fig. 6

Some in-game songs are from a time period during which the Beatles gave up playing live. For these songs, Lennon, McCartney, Harrison and Starr are shown in the recording studio, but these videos also tend to include extra animation. Sometimes the animation references Beatles movies like Magical Mystery Tour or Yellow Submarine. Other times it seems to be just a general reference to psychedelic 60s nostalgia, with very bright colors and kaleidoscopic patterns of little discernible meaning (Figures 8 and 9). These images arguably fit both the popular idea of the 
Beatles' in the late 60s (as seen in movies like A Hard Days Night or Yellow Submarine), as well as romantic notions of 60s hippie culture more generally. Curiously, one of the in-game songs was never produced as part of the original Beatles catalogue, but is actually a remix of two different songs: "Tomorrow Never Knows" and "Within You Without You". This mash-up was created for the Beatles remix album called Love, a soundtrack from a Cirque du Soleil show of the same name, which was released in November 2006. Despite the fact that this mash-up was never recorded by the original band, the video accompanying game play shows the Beatles singing and playing the song together (Figure 9).

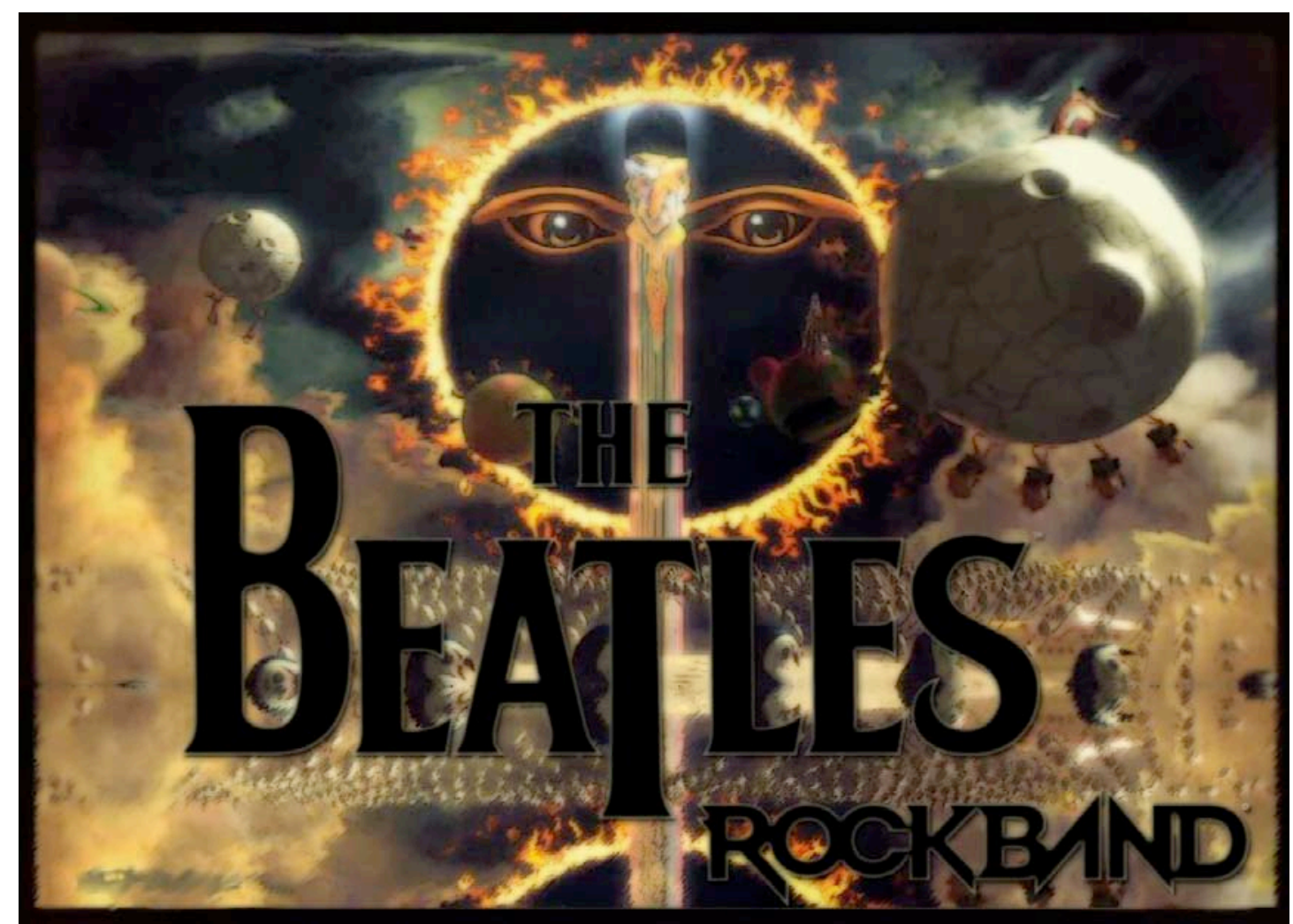

Figure 8: An image from the game with references to the psychedelic 1960s and to Eastern spirituality. Images of the sun and eyes are often present in Hindu cultural artifacts.

All of the songs and images portrayed in the game reinforce an already rock-solid brand. The Beatles are much more than just a musical group. They are Apple Corps. Ltd.'s only brand, and arguably one of the most well-known brands in the history of popular music. Thus, Beatles Rock Band is not just a digital interpretation of a well-known musical group, it is a remediation of many different well-known multi-media interpretations of that group. It is based on several tropes that were developed and refined through albums, motion pictures, television shows, action figures, graphic novels, fan clubs, and of course the musicians themselves. However, the real people who make up the Beatles are somewhat lost in this process of branding, since fully realized human beings are much more difficult to remediate. 


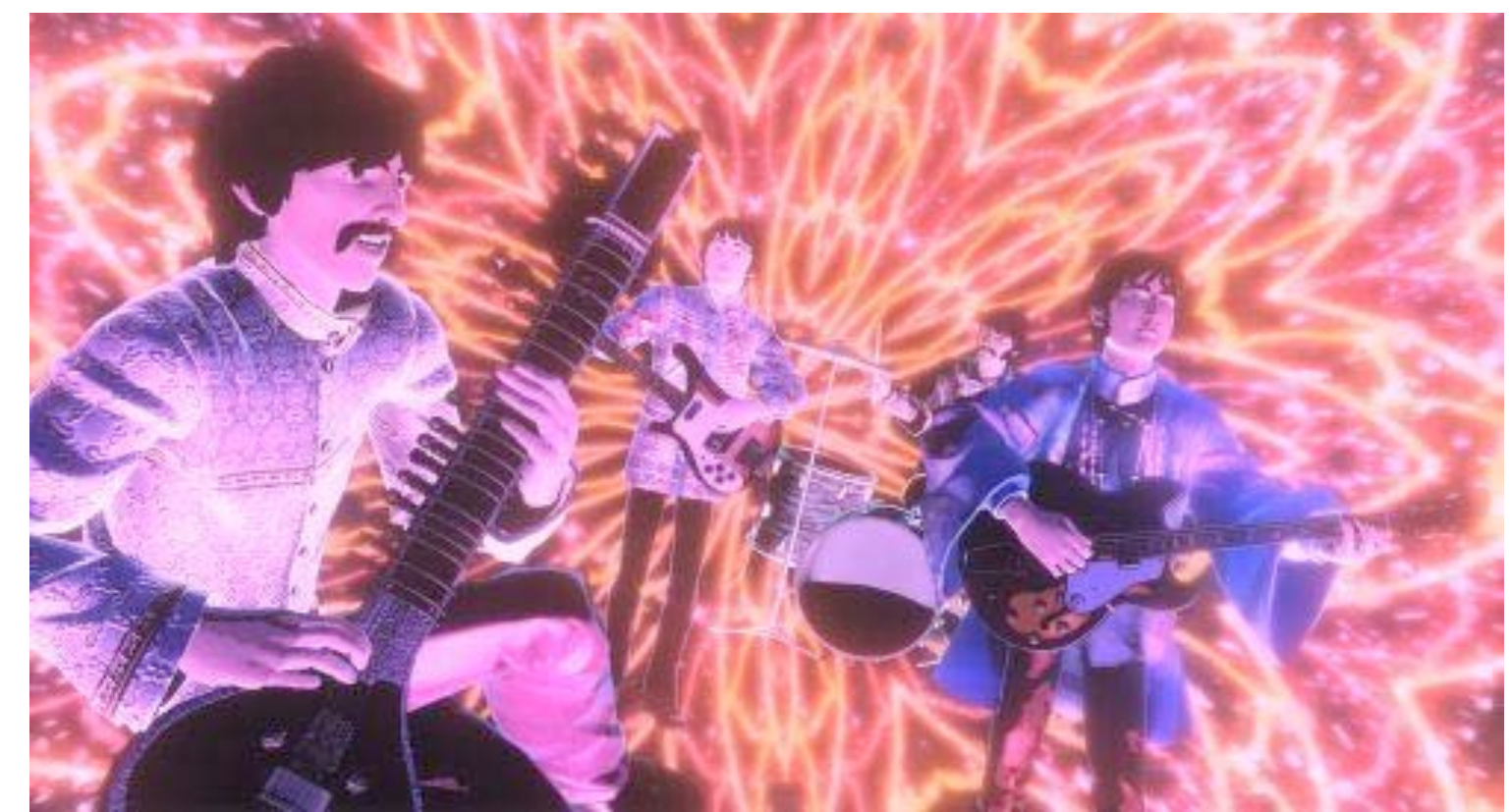

Figure 9: A psychedelic still of the Beatles Playing together in the remixed song "Within You Without You/Tomorrow Never Knows"

\section{Sgt. Pepper's Lonely Hearts Club Brand: A review of the Beatles Branding and how it led to Beatles Rock Band}

Modern branding is a complex process whereby the image of a brand becomes more important than the product or service it represents (Lury, 2006). In general, brands accomplish this feat by appealing to people's deep-seated emotional needs and desires. Brands stand in for intangible ideals such as love or social connection. They sell products not based on any material or practical value, but on the promise of the fulfillment of needs that the product itself could never possibly meet (Klein, 2001). In the cultural industry, particularly the music industry, branding takes on a new dimension, as what's being branded is often not a passive product, but an active feeling, thinking, complex person or set of people. The Beatles are an interesting example this type of branding because over the years they have developed a very well-established brand image. In turn, Beatles Rock Band takes the already existing Beatles brand to a new level by combining two existing successful brands: the Beatles and the Rock Band franchise. In this co-branded production, every detail about the band that does not fit a neutralized, capitalist myth of the Beatles has been whitewashed and virtually eliminated from the in-game history of the group. But this branding did not originate with Harmonix, or the Beatles Rock Band game. On the contrary, it evolved over time and across media through movies, music albums, remixes, cartoons, action figures, and finally video games.

The branded characters that we know as John Lennon, Paul McCartney, George Harrison and Ringo Starr probably emerged with the start of the Beatles' motion picture career. As John Lennon described in a 1971 interview on the Dick Cavett show, the idea of the Beatles that emerged from the popular film A Hard Day's Night, was only loosely based in any lived reality:

"[The situation portrayed in the film A Hard Day's Night] was a sort of comic strip version of what actually was going on, the pressure was far heavier than that. 
And that was written after the author, spending about three days with us when we played in London, and then in Dublin, and then back in London again. He wrote the whole of the film based on our characters, you know, 'Clod-hopping Ringo', 'Sharp' John, 'Whimsical' Paul and 'Stern' George, and all those, the Beatle character myths were formed from three days watching us, you know? Which... was a lot of junk, really"

Dick Cavett Show (1971)

Once immortalized in that first film, however, these caricatures became the go-to representation of the Fab Four, and were continually reinforced in four other films, cartoons, special album releases such as the Beatles Anthologies, which included specially chosen clips of the band speaking, and countless other media.

For marketers, turning the Beatles into characters was a smart move. The wholesome but playful boys from A Hard Day's Night could appeal to a broad demographic, which allowed for transmediation (Jenkins, 2007) - sales of action figures, lunch boxes and television shows - to go along with the primary product produced by the band, their music. For journalists, the Beatles' characters were also helpful. They allowed for an easy shorthand, and they were ample fodder for drama when the real Beatles did not live up to the expectations of their caricatures (such as when the boys returned their medals from the queen in an act of protest).

This successful shorthand has resulted in a brand that continues to endure over time. The commodification of the Beatles has continued to attract new audience members and consumers for decades. While previously the Beatles were sold as action figures, recorded music, movies, and books, Beatles Rock Band represents the entry of the Beatles brand into video gaming and thus is a continued expansion of the brand's transmediated presence (Jenkins, 2007). This opens up a market in which consumers who already own the product will buy songs they already own on another medium, in order that they can use the song with the game. As such, this particular remediation (Bolter \& Grusin, 1999) of the Beatles potentially opens up a brand new market (video game players) for the original brand, and also attracts an old market (Beatles fans) to the new medium of video games. In doing so, the game creates a commodity fetishism based not on commodified play, which we see in video games marketed to children, but rather, commodified nostalgia - a type of commodification aimed at a potentially broader audience.

\section{Can't buy me love: The commodification of nostalgia}

In their book Digital play: The interaction of technology, culture and marketing, Kline, DyerWitheford and De Peuter (2005) showed the ways video games in the 1980s and 1990s were marketed to young people. They found that video games commodified children's play, changing it from a free, unbounded creative act to a bounded, structured event focused around a particular commodity. Today, the children that were playing video games during Kline, Dyer-Witheford and De Peuter's (2005) study have grown up, and the video game industry has grown with them. Rather than just a commodification of play, Beatles Rock Band is a game that also commodifies nostalgia. Just as Pokémon games took advantage of a well established cross-platform brand in order to sell more product, Beatles Rock Band uses a well established existing brand in the same 
way and in doing so also reaches out to a new demographic - one which includes older adults - in an effort to remain competitive in a tough marketplace.

The colorful but neutralized images in the game ensure a broad appeal, as does the rewrite of history that fits nicely with the Beatles already existing brand. But this rewrite of history is accompanied by a potentially stiff social price tag. Kline, Dyer-Witheford and De Peuter (2003) remarked on how the video game industry in the 1980s and 1990s reinforced a type of hegemonic masculinity that encouraged the glorification of violence through a type of social conditioning reminiscent of Gerbner's (1994) cultivation theory. Beatles Rock Band contains no violent imagery, but it does paint an unrealistic view of the past that aims to support dominant systems of power and capital. This view of history is reinforced throughout the Beatles brand, and it is not a stretch to suggest that these texts when taken together offer a history devoid of resistance and revolution. Events like the Beatles returning their MBE medals to the Queen, or John Lennon's bed-in for peace are left out of the narrative completely.

We often forget that the 1960s and 1970s were a period of great civil unrest and upheaval in North America and Europe (Holmes, 2010). One of the reasons for this collective memory lapse seems to be the fact that popular discourses about that time period focus on romanticizing the struggle. The 1960s and 1970s are portrayed in a way that neutralizes most of the popular ideas of revolution and struggle, along with the revolutionary power that was present in the actions of the time. Since discourse is a productive force which helps to create identity and make meaning in the world (Foucault, 1980; Butler, 1990), modern popular discourses about the 1960s and 70s serve to legitimate some aspects of history, while delegitimizing or removing others. These discourses are repeated in popular culture texts such as movies and video games because they serve an economic purpose. A cultural product becomes more palatable to the consumer when it includes the values and feelings that the rest of life does not provide. In this case, the cultural product becomes a Marxian fetish object. The video game stands in for such values as freedom, innocence, community, "free" love and even joy (Debord, 1967; Marx, 1867). This effect may be much more pronounced when it occurs through cultural products that are really intended to be representations of some objective reality - news stories, documentary films, and more recently, documentary games.

In an analysis of the documentary game JFK: Reloaded, Poremba (2009) notes some of the dangers of games based on real life events. In her analysis, she notes the ways games can become meaning-building frames, and she reminds us, following Black, that we need to ask of our play not only "How do we play the game?" but also "Is this the game we want and ought to play?" Furthermore, in a similar study of documentary games including Medal of Honor, Waco Resurrection, JFK: Reloaded and 911 Survivor, Fullerton (2008) asks: "what can we learn from documentaries in which we participate, and how do these experiences add to our understanding of historical events and the issues surrounding them, rather than simply allowing us to 'be in the moment" (p. 26). It is true to say that documentary video games have neither reached the cultural status of documentary motion pictures, nor in some cases their verity. In the case of games like Beatles Rock Band, which in some ways do not even attempt an accurate retelling of history, this seems especially true. Though players play through songs, rather than the specific events themselves, as the player moves through the game, actual events are depicted in chronological order, as part of the storyline. For this reason, I recommend that researchers do not 
shy away from analyzing these games, and any other Rock Band game based on real life people and events as documentary games. This is because these games contain enough material based in reality that they suggest a preferred retelling of human history. Furthermore, because they do not deal with controversial topics such as Waco, the JFK assassination or 911, they are more likely to be dismissed by researchers as party games in which players simply recreate pop songs, and thus not subjected to the same historical or critical scrutiny as other documentary games even though they are played by a much larger audience.

Writing about the popular game Sim City, Milaucic (2006) suggested that the environments portrayed in the game "deny at fundamental levels any real lived experience" (para. 30). In doing so, they reduce any and every activity to the basic logic of consumption. These representations then, serve to reinforce dominant ideologies, of capital accumulation and production. While game environments could be used to challenge existing norms and values, the programming of the game tends to dictate a preferred method of play, and in the case of Sim City, that method serves to support the status quo. Similarly, nostalgia in games like Beatles Rock Band offers players a preferred reading of popular historical events, and this reading or experience of the past supports commodification of history and maintaining a status quo in which popular music and the musicians who create it are depoliticized. In other words, Beatles Rock Band gives me the freedom to inhabit the body of my favorite Beatle, and play an instrument I've never practiced, but even as it makes me a cyborg musician, "the constructed technobody reinforces the predominant power relations and the supremacy of the ... state" (Poblocki, 2002, p. 172). As the songs and the history portrayed in Beatles Rock Band are depoliticized, history itself becomes just another tool in service of corporate profit. In a sense, history as portrayed in the game becomes part of the Beatles brand, and as such players are invited to adopt a non-critical stance towards this history, and towards the organizations that aim to commodify it, in a kind of postmodern co-optation of an ephemeral nostalgia.

\section{Nostalgia and Capital}

The Rock Band games take musical play and channel it in a very specific way, one that is best for the dominant culture of capital production. In doing so, the process of transmediation and remediation described by Bolter and Grusin (1999), Jenkins and Lury leads to the creation of copies placed upon copies ad-infinitum. Over time, only copies remain and the original is lost. This phenomenon is not exclusive to the new digital representations of the Fab Four. In fact, since they were first marketed, the Beatles have been simulacra, impossible to separate from their real and material human forms. In this sense, the game is just the latest iteration of an illusion created and sustained by the intersection of capital and popular culture. The Beatles, as portrayed in Beatles Rock Band, are a copy of a copy, or what Baudrillard termed the hyperreal. The hyperreal Beatles are most apparent in the use of the mash-up song "Tomorrow Never Knows/Within You Without You" as part of the history of the Beatles' musical career within the game. The mashed-up song that never existed is portrayed in-game as part of the Beatles' original recorded catalogue. As a person plays the song, the video shows the four Beatles sitting down together to record the song as it sounds to the player. There is no indication that this mash up was actually created 50 years after the Beatles broke up. This unreal moment dilutes the meaning of each individual song in the mash-up and represents one of the moments in which the game is exposed as fantasy. In creating copies from copies, the music and related images in Beatles Rock Band, have no revolutionary power - they are parody, carnivalesque, and spectacle 
(Debord, 1967) in service of postmodern capitalism. Beatles Rock Band therefore represents the apotheosis of a long process of commodification.

Jameson (1991) wrote that history is not an accurate representation of the past, nor a representation of the future, but instead should be thought of as the present perceiving itself. In fact, the only way the present can conceptualize of itself is through the lens of a history that is more or less, fictional. The 'real' Beatles, if there is such a group of people, are not present in our rear-view-mirror interpretation of them, or as Jameson wrote, "the period [did not] see itself this way" (p. 279). As a retelling of present concerns through the lens of the past, nostalgia films train us to think of the past as something that can be consumed, and we can argue that nostalgic games in some ways achieve the same ends. Thus, "the schizophrenic, drug-cultural side of the sixties is here systematically excluded along with its politics" (p. 292). Politics does not sell. The suburban culture of the 1950s, which the 1960s and 1970s countercultural movements were responding to, is itself historicized and commodified in other cultural texts, and thus is neutralized elsewhere. Generally, nostalgia is based on the illusion of a specific past, but the yearning for that past is the yearning for a dream-something that never really existed. In this sense, Beatles Rock Band fits Jameson's discussion of nostalgia films quite readily. And unfortunately, unlike other game environments which offer opportunities for resistant discourses via alternate modes of play (Parker, 2008; Poremba, 2010), the myth of the Beatles established before the game even existed, along with the limited nature of the user experience present in the Rock Band games as a whole, makes off script or modified player activity an impossibility. In other words, materially there are only two options for a Rock Band player. She can push a button in order to play a note, or she can choose not to. She cannot move her avatar at all either inside or outside each song, and while she can choose to play wrong notes (by pushing an incorrect button) doing so will earn her avatar the disdain of the in-game audience, and soon result in the end of the game. In addition, the player does not have the choice in game to specify that his Beatle avatars switch instruments. He also cannot play an early Beatles song using a representation of the Beatles from later in their career. In fact, each background, representation of the band and animated video during the song is pre-selected by the game artists and programmers to correspond to an accepted (and popular) history of the band. It is likely that any other representation would be rejected by the very fan community the game strives to attract. And any fan community of practice that is brought together through the game seems to, if anything, serve to reinforce the commercial popularity of the game commodity.

\section{Fan Communities}

A search for "Beatles Rock Band" on the popular video sharing site YouTube reveals over 137,000 videos relating to the game. A quick scan of these videos shows that while some videos are game trailers or other marketing vehicles, most are made and uploaded independently by users and represent recordings of their experience of the game, reviews of the game, and video remixes that reimagine songs or sequences that were not originally included in the game release. When these videos are left open to comments, they include posts by a community of enthusiastic Beatles fans. While not all comments to videos are supportive, the majority are, making these YouTube videos potential sites for the creation of fan communities. Fans share their achievements ("5 stars on Day Tripper - WooHoo!") and they discuss their relationship with the Fab Four ("Paul's my favorite"). Right now, these communities seem to be primarily concerned with sharing their experience of the game with each other - an action that promotes the product 
and thus furthers the economic imperative of the companies that have a stake in the Beatles or Rock Band franchises. But these activities highlight an opportunity for a possible re-imagining of how individuals could interact within or through the game space. Fan communities serve the brand, but they can also be important sites for the discussion and sharing of issues relevant to a broader social and moral framework in society (Jenkins, 2006). Therefore, we can think of the relationships between individuals and cultural texts as a complex battleground of negotiated, preferred, and oppositional readings (Hall et. al., 2001). These are sites where ideologies are created and reinforced, but also ones in which groups can strive to undermine them.

\section{Simulated History and Opportunities for Resistance}

If Beatles Rock Band is to escape the commodification of nostalgia, the impetus will arise out of the labour of the fan community. A YouTube search makes it very clear that people can take parts of the game and remediate them for their own purposes. However, a quick scan also reveals that currently this remediation works in service of the commodification of the game. However, one can imagine potential engagement with this text where this is not the case. In theory, people could remix the videos in resistant ways, or use the commenting features within YouTube to explore larger issues than whether John or Ringo is their favorite Beatle. People could build communities of practice through their engagement with this text that could invite discussions of other issues of greater importance. And people could walk away with bonds to other networked individuals that result in stronger social circles, more resilient communities, and greater opportunities for engagement. Currently, a cursory analysis of the comments on the Beatles Rock Band YouTube videos show little evidence of any civic or community-focused communication occurring. Despite this however, it is important to note that the potential of fan communities as sites of resistance remains, even if they are not manifesting that potential in their current iteration. Furthermore, the game text itself, with its cheery cartoon representations and psychedelic animations may open up unique but subtle opportunities to resist the ubiquitous Beatles fantasy by shedding light, in true postmodern fashion, on the very inauthenticity of the Beatles branding. It is here that we are well-served by a reading of Beatles Rock Band as a documentary game, because with the unique opportunities for reflexivity afforded to game players, the gap between reality and the text can provide moments in which the in game nostalgia reveals the Beatles' own hypermediation.

The opening cinematic described earlier in this paper is a cartoon culminating in a parade of egg men and a giant blue elephant. No less a false depiction of a series of events once based in reality is found in the game videos themselves where the Beatles are portrayed playing songs that never existed, in a studio with no technicians, or even in completely invented dreamspaces (for example, both the "Yellow Submarine" and "Octopuses Garden" animations portray the Beatles at the bottom of the ocean). In this game, ostensibly based on the Beatles' career, the Beatles are always clean cut and they never break up nor age. But it is the game as simulacra, a postmodern interpretation of an interactive music documentary, that can reveal the limitations of the Beatles brand as an orientational object. When the Beatles are portrayed in a movie that blurs the lines between reality and fiction, such as Hard Day's Night or Help it is easy to accept a branded interpretation as an indication of what the individuals may have been like. This leads viewers to either accept a preferred version of reality, one which eliminates the countercultural or subversive aspects of the 1960s in service of capital or reject the branded reality altogether and search for an alternate truth. However in Beatles Rock Band, players are presented with the 
opportunity to go beyond this black and white version of truth and fiction. Instead, the very obvious constructed nature of this text serves to remind us of the extent to which the Beatles have always been constructed. Players are thus invited to move beyond a search for an authentic history, and are invited recognize that their nostalgia is colored by the desire for a past and present that don't really exist.

\section{Nothing is Real: Postmodern Nostalgia and Resistant Readings}

While people may not be able to play off script due to the mechanics of this game, they can certainly adopt an oppositional reading to the Beatles Rock Band text, and like a Warhol painting, resistant readings of this particular interpretation of history lie in its blatant rejection of authenticity. Thus, the game can actually reveal much more than a direct retelling of history would, because for some players the simulation portrayed herein can serve as a present reminder of the constructed nature of the entire Beatles branding project. It reminds each of us that we should not accept the interpretation of the Beatles as portrayed in A Hard Days Night, nor should we accept them as "Sergeant Pepper's Lonely Hearts Club Band". Instead, players are called upon to recognize each and every one of these mediated and nostalgic subjectivities as a fiction, a game we play with ourselves and in our own heads. We can play remixed tracks within a psychedelic dreamscape of 'cellophane flowers' without thinking twice about the fantastic nature of the game audio and visual representations because the Beatles never existed outside of representation in the first place. We, as players in our Beatle avatar, can re-enact an imagined and nostalgic British invasion from apartments in Winnipeg as part of a brand community brought together through a participatory and postmodern media form. And as we do, we are invited to consider our own relationship with history and the dream of a past that reflects our present realities. Since our relationship to in-game avatars is complex, liminal, and reflexive (Boudreau, 2012), a video game text may be the best place to engage in this type of critical reading. Whether or not players of Beatles Rock Band are adopting oppositional readings along these lines however still remains to be seen. Future work still needs to be completed to establish whether players of the Rock Band game franchise, and in particular band-specific games like Beatles Rock Band think critically about the images of music history as portrayed through the game animations.

John Lennon asked us to imagine no possessions. Now his image and his voice are being used to sell video games, video game systems, and digital music tracks people already own so that they can play a game in which Lennon is a parody of himself. It is important that we understand the marketing push behind games like these, so that we can participate in an oppositional reading of texts that seek to neutralize history in favour of commodity. If we do this, we can use these games as texts that help us understand the extent to which history is always rewritten to support a dominant ideology - opening up opportunities for resistance. If we do not attend to this however, we will allow large remediated brand expressions to rewrite history in a way that undermines the very people who used to struggle against them. Subcultural texts have historically been coopted and reproduced in service of dominant interests (Hebdige, 1981). When we recognize the fallacy in romanticizing these nostalgic social movements, we may make their co-optation less straightforward. As a post-modern text, a game like Beatles Rock Band, which exists as part of a long system of hypermediation, is currently a site where capital co-opts and controls popular culture by commodifying a very human longing for the past. At their best, however, video games 
can be reimagined instead as sites where the fallacy of nostalgia could be revealed. If we can read game texts in this way, then games like Beatles Rock Band can serve to remind us, in the words of the Lads from Liverpool themselves, that indeed "nothing is real" (Lennon/McCartney, 1967). And this fact can help us to understand the complex relationship between our longing for the past and our existence in a commodified present. 


\section{References}

America's hottest brands [Electronic (2009). Version]. Advertising Age from http://adage.com/article?article id=140445.

Barthes, R. (1957). Mythologies. New York: Hill and Wang.

Baym, N. (1993). Interpreting soap operas and creating community: Inside an electronic fan culture. Journal of Folklore Research, 30, pp. 143 - 176.

Beatles Rock Band. (2010). Retrieved May 1, 2010, from http://www.thebeatlesrockband.com/

Benjamin, W. (1936). Work of art in the age of mechanical reproduction. New York: Schocken.

Bogost, I. (2007). Persuasive games: The expressive power of videogames. Cambridge, MA: MIT Press.

Bolter, J. D., \& Grusin, R. (1999). Remediation. Boston: MIT Press.

Boudreau, K. (2012). Between play and design: The emergence of hybrid-identity in singleplayer videogames [dissertation]. Retrieved October 20, 2012 from http://umontreal.academia.edu/KellyBoudreau/Papers

Butler, J. (1990). Gender trouble: Feminism and the subversion of identity. New York: Routledge.

Butler, J. (1993). Bodies that matter: On the discursive limits of sex. New York: Routledge.

Cote, M., \& Pybus, J. (2007). Learning to immaterial labour 2.0: Myspace and social networks. Ephemera, 7, pp. 88-106.

Debord, G. (1967). Society of the spectacle [Electronic Version]. Retrieved May 1, 2010 from http://www.marxists.org/reference/archive/debord/society.htm.

Dick Cavett Show (1971). USA: ABC.

Elmer, G., \& Opel, A. (2008). Preempting dissent. Winnipeg: Arbeiter Ring Press.

Foucault, M. (1980). The history of sexuality: Volume 1. New York, NY: Vintage Books.

Foucault, M. (2002). Abnormal: Lectures at the College de France, 1974-1975 (G. Burchell, Trans.): Picador.

Friedman, T. (1999). The semiotics of SimCity [Electronic Version]. First Monday, 4. Retrieved May 1, 2010 from: http://firstmonday.org/htbin/cgiwrap/bin/ojs/index.php/fm/article/view/660/575.

Fuller, M., and Jenkins, H. (1995). Nintendo and new world travel writing: A dialogue. Retrieved August 1, 2011 from: http://www.stanford.edu/class/history34q/readings/Cyberspace/FullerJenkins_Nintendo.h tml

Fullerton, T. (2008). Documentary games: Putting the player in the path of history. In Z. Whalen and L. Taylor (Eds.) Playing the past: Nostalgia in video games and electronic literature. Nashville: Vanderbilt University Press.

Gerbner, G. (1994). Reclaiming our cultural mythology. Ecology of Justice, 38.

Gruenewald, D. A. (2004). A Foucauldian analysis of environmental education: Toward the socioecological challenge of the earth charter. Curriculum Inquiry, 34(1), pp. 71-107.

Hall, S., Meenakshi G. D. and Kellner, D. Eds. (2001). Encoding/Decoding, in Media and cultural studies: Keyworks. pp. 17.

Hartmann, T., \& Klimmt, C. (2006). Gender and computer games: Exploring females' dislikes [Electronic Version]. Journal of Computer Mediated Communication, 11. Retrieved May 1, 2010 from http://jcmc.indiana.edu/vol11/issue4/hartmann.html.

Hebdige, D. (1981). Subculture: the meaning of style. London: Routledge. 
Holmes, B. (2010). Continental drift. Retrieved May 1, 2010, from http://brianholmes.wordpress.com/

Huffaker, D. A., \& Calvert, S. L. (2005). Gender, identity and language use in teenage blogs [Electronic Version]. Journal of Computer Mediated Communication, 10. Retrieved March 30, 2008 from http://jcmc.indiana.edu/vol10/issue2/huffaker.html.

Jameson, F. (1991). Postmodernism or the cultural logic of late capitalism. Durham, NC: Duke University Press.

Jenkins, H. (2006). Convergence: When old and new media collide. New York: NYU Press.

Johnson, T. J., Kaye, B. K., Bichard, S. L., \& Wong, W. J. (2007). Every blog has its day: Politically interested internet users' perceptions of blog credibility [Electronic Version]. Journal of Computer Mediated Communication, 13. Retrieved March 30, 2008 from http://jcmc.indiana.edu/vol13/issue1/johnson.html.

Kim, J., Lee, E., Thomas, T., \& Dombrowski, C. (2009). Storytelling in new media: The case of alternate reality games, 2001-2009 [Electronic Version]. First Monday, 14. Retrieved May 1, 2010 from http://firstmonday.org/htbin/cgiwrap/bin/ojs/index.php/fm/article/view/2484/2199

Klein, N. (2001). No logo: Taking aim at the brand bullies. Toronto: Random house.

Kline, S., Dyer-Witheford, N., \& De Peuter, G. (2005). Digital play: The interaction of technology, culture, and marketing. Montreal: McGill-Queens University Press.

Lennon/McCartney (1967). "Strawberry Fields Forever" [Musical Track]. Sergeant Peppers Lonely Hearts Club Band. London: EMI

Lury, C. (2004). Brands: The logos of the global economy. London: Routledge.

Markham, A. N. (2006). Ethic as method, method as ethic: A Case for reflexivity in qualitative ICT research. Journal of Information Ethics, 15(2), pp. 37-54.

Marx, K. (1867). Capital Volume 1 Retrieved Feb 25, 2010, from http://www.marxists.org/archive/marx/works/1867-c1/ch01.htm\#S4.

McLuhan, M. (1964). Understanding media: The extensions of man. New York: Mcgraw-Hill.

Milaucic, S. (2006). Virtual real(i)ty: Sim city and the production of urban cyberspace. Retrieved August 15, 2011 from: http://game-research.com/index.php/articles/virtualreality-simcity-and-the-production-of-urban-cyberspace/

Parker, F. (2008). The significance of jeep tag: On player-imposed rules in video games. Loading... 2(3).

Pentzold, C., \& Seidenglanz, S. (2006).Foucault@Wiki: First steps towards a conceptual framework for the analysis of wiki discourses. Retrieved April 15, 2010, from http://www.wikisym.org/ws2006/proceedings/p59.pdf

Poblocki, K. (2002). Becoming-state: The bio-cultural imperialism of Sid Meier's Civilization. Focaal: European Journal of Anthropology 39. pp. 163-177. Retrieved Aug 15, 2011 from http://amu.academia.edu/KacperPoblocki/Papers/335927/Becoming-State

Poremba, C. (2009). Frames and simulated documents: Indexicality in documentary videogames. Loading 3(4). n.p. Retrieved Aug 1, 2011 from http://journals.sfu.ca/loading/index.php/loading/article/view/61/60

Poremba, C. (2010). Discourse engines for art mods. Eludamos. Journal for Computer Game Culture 4 (1), pp. 41-56

Postigo, H. (2010). Modding to the big leagues: Exploring the space between modders and the game industry [Electronic Version]. First Monday, 15. Retrieved May 1, 2010 from http://firstmonday.org/htbin/cgiwrap/bin/ojs/index.php/fm/article/view/2972/2530 
Project, P. I. a. A. L. (2007). Adults and video games [Electronic Version]. Retrieved May 1, 2010 from http://www.pewinternet.org/Reports/2008/Adults-and-Video-Games/1-Data-Memo/01Overview.aspx? $\mathrm{r}=1$.

Rock Band [Electronic (2010). Version]. Wikipedia, the Free Encyclopedia. Retrieved May 1, 2010 from http://en.wikipedia.org/wiki/Rock Band \%28video game $\% 29$.

Smith, M. A., Farnham, S. D., \& Drucker, S. M. (2000). The social life of small graphical chat spaces. CHI Letters, 2(1), pp. 462 - 469.

Steinkuehler, C., \& Williams, D. (2006). Where everybody knows your (screen) name: Online games as "third places" [Electronic Version]. Journal of Computer Mediated Communication, 11. Retrieved May 1, 2010 from http://jcmc.indiana.edu/voll1/issue4/steinkuehler.html.

Terranova, T. (2009). Another life: The nature of political economy in Foucault's genealogy of biopolitics. Theory, Culture and Society, 26, pp. 234-262.

Thelwall, M., \& Stuart, D. (2007). RUOK? Blogging communication technologies during crises [Electronic Version]. Journal of Computer Mediated Communication, 12. Retrieved March 30, 2008 from http://jcmc.indiana.edu/vol12/issue2/thelwall.html.

Trammell, K. D., Tarkowski, A., Hofmoki, J., \& Sapp, A. M. (2006). Rzeczpospolita blogow [republic of blog]: Examining Polish bloggers through content analysis [Electronic Version]. Journal of Computer Mediated Communication, 11. Retrieved March 30, 2008 from http://jcmc.indiana.edu/voll1/issue3/trammell.html.

Tschang, F. T., \& Comas, J. (2010). Developing virtual worlds: The interplay of design, communities and rationality [Electronic Version]. First Monday, 15. Retrieved May 1, 2010 from http://firstmonday.org/htbin/cgiwrap/bin/ojs/index.php/fm/article/view/2957/2525

Turkle, S. (1995). Life on the screen: Identity in the age of the internet. New York: Simon \& Schuster.

Turkle, S. (2011). Alone together. Why we expect more from technology and less from each other. New York: Simon \& Schuster. 